\title{
The role of radiotherapy in metastatic bladder cancer
}

\author{
Jananie Perera ${ }^{1}$, Peter Hoskin ${ }^{1,2}$ \\ ${ }^{1}$ Mount Vernon Cancer Centre, Rickmansworth Road, Northwood, Middlesex HA6 2RN, UK. \\ ${ }^{2}$ Division of Cancer Sciences, University of Manchester, Manchester M20 4GJ, UK.
}

Correspondence to: Prof. Peter Hoskin, Mount Vernon Cancer Centre, Rickmansworth Road, Northwood, Middlesex, HA6 2RN, UK. E-mail: peterhoskin@nhs.net

How to cite this article: Perera J, Hoskin P. The role of radiotherapy in metastatic bladder cancer. J Cancer Metastasis Treat 2022;8:4. https://dx.doi.org/10.20517/2394-4722.2021.167

Received: 28 Aug 2021 First Decision: 19 Nov 2021 Revised: 29 Dec 2021 Accepted: 4 Jan 2021 Published: 25 Jan 2022

Academic Editor: William P. Schiemann Copy Editor: Yue-Yue Zhang Production Editor: Yue-Yue Zhang

\begin{abstract}
The management of metastatic bladder cancer is palliative. Best outcomes are achieved in those who are fit enough for systemic therapies. The place of radiotherapy in these patients is mainly for symptom control, in particular haematuria. However, a small proportion, especially those with oligometastases, will benefit from more radical treatment. In this review, we look at the evidence currently available for radiotherapy in this setting.
\end{abstract}

Keywords: Bladder cancer, radiotherapy, oligo metastases, haematuria, bone metastases, brain metastases

\section{INTRODUCTION}

Bladder cancer is the ninth most common cancer in the world ${ }^{[1,2]}$. The main histological subtype is urothelial carcinoma. It is a disease of the elderly and tobacco smokers with both of these impacting the ultimate prognosis. Around one-fifth will present with metastatic disease, and only about one-third of these will survive over a year ${ }^{[3]}$. In addition, half of those with muscle invasive disease treated with curative intent eventually relapse with nearly $50 \%$ of them developing distant metastasis ${ }^{[4,5]}$.

The management of metastatic bladder cancer is palliative. Prognosis is poor even in those fit enough for treatment. The treatment of choice remains platinum-based chemotherapy with a weak recommendation 
for first line immunotherapy for those not fit enough for cytotoxic chemotherapy ${ }^{[6]}$. Cisplatin-based chemotherapy achieves a median overall survival (OS) of up to 15 months $\mathrm{s}^{[7]}$. The addition of maintenance immunotherapy has the potential to increase the median overall survival to 21.4 months $^{[8,9]}$. In the UK, some form of radiotherapy is used in almost $30 \%$ of those with metastatic disease within 12 months of diagnosis ${ }^{[3]}$.

Long-term follow-up data from palliative chemotherapy trials have shown a 10\%-20\% 5 year survival suggesting the existence of a subgroup with a good prognosis ${ }^{[7,10]}$. In addition, several surgical series have shown survival benefit with metastasectomy in both synchronous and metachronous settings ${ }^{[1-16]}$. There is also limited evidence of the benefit with ablative radiotherapy in selected patients with oligometastases.

The role of radiotherapy remains mainly palliative. There is limited evidence for its use in consolidative therapy post-chemotherapy and more radical ablative treatments for oligometastatic disease.

\section{Palliative bladder radiotherapy}

Radiotherapy is commonly used to control haematuria as well as other bladder symptoms like dysuria, frequency, and pain. A survey conducted by the Royal College of Radiologists in the UK in the early 1990 s found a multitude of dose fractionation regimens being used with 30 Gy in 10 fractions being the most common $^{[17]}$. A more recent review of palliative practice in two leading cancer centres in the UK has shown a similar spread of dose fractionation schedules still being used ${ }^{[18]}$. Several studies have looked at different dose fractionation schedules in this setting and found them essentially similar in effectiveness and toxicity [Table 1]. Most of the trials included heterogeneous populations of patients unsuitable for radical treatments and were for both advanced symptomatic local disease as well as metastatic disease. This needs to be considered when interpreting symptom-free survival benefit. One consistent finding, however, is the efficacy in achieving haemostasis in patients presenting with haematuria.

The largest and the only randomized controlled trial on the subject was Medical Research Council (MRC) BA09 (19). It randomized 500 muscle invasive bladder cancer patients, either unfit or too advanced for radical treatment between the then standard of care of 35 Gy 10\# and 21 Gy 3\#. Only 40 patients with confirmed metastatic disease were included. The benefit was defined by an improvement in at least 1 symptom without deterioration of any others. No statistically significant difference was seen at the end of the treatment or after 3 months for efficacy or toxicity between the two fractionation schedules. Over onefifth of the cohort had died by the 3-month assessment, and there was no improvement in quality of life for almost two-thirds of the survivors. At the end of treatment, a significant proportion had worse symptoms which improved with time ${ }^{[19]}$. Similar findings have been seen with other studies evaluating hypofractionation schedules with reported acute toxicity being in the range of $20 \%-50 \%{ }^{[20-23]}$.

Despite the findings of the MRC study the most common schedule in use is $30 \mathrm{~Gy}$ in 10\#, possibly reflecting uncertainty around the use of fraction sizes of $7 \mathrm{~Gy}$ in the pelvis. In a similar population of patients to those in the MRC study, only haematuria and incontinence showed improvement in those surviving at 3 months with this schedule. This was presumed to be due to the low radiobiological dose delivered with this fractionation schedule ${ }^{[24]}$.

Since the full benefit of treatment over acute radiation toxicity may take some months to emerge, the most important focus is to identify those who will actually benefit from palliative radiotherapy with a life expectancy of more than three months. 
Table 1. Summary of large studies on palliative bladder radiotherapy

\begin{tabular}{|c|c|c|c|c|c|}
\hline $\begin{array}{l}\text { Study (study } \\
\text { design) }\end{array}$ & Fractionation & Stage & Symptom control & $\begin{array}{l}\text { Median } \\
\text { survival }\end{array}$ & $\begin{array}{l}\text { Bladder/bowel } \\
\text { toxicity }\end{array}$ \\
\hline $\begin{array}{l}\text { Ali et al. }{ }^{[18]} \\
\text { (Retrospective cohort) }\end{array}$ & $\begin{array}{l}8 \text { Gy } 1 \# \\
21 \text { Gy } 3 \# \\
20 \text { Gy5 \# } \\
36 \text { Gy } 6 \# \\
30 \text { Gy } 10 \#\end{array}$ & $\begin{array}{l}\text { T1-4N1- } \\
3 \mathrm{MO}-1\end{array}$ & $\begin{array}{l}\text { EOT } 53 \% \\
\text { Hematuria 54\% } \\
\text { Dysuria and frequency 57\% } \\
\text { Pain } 48 \%\end{array}$ & $\begin{array}{l}\text { Median OS 5/12 } \\
\text { (M1: } 3.2 / 12)\end{array}$ & NR \\
\hline $\begin{array}{l}\text { Duchesne et al. }{ }^{[19]} \\
\text { (RCT) }\end{array}$ & $\begin{array}{l}35 \text { Gy } 10 \# \text { vs. } 21 \mathrm{~Gy} \\
\text { 3\# }\end{array}$ & $\begin{array}{l}\text { T2-4NO- } \\
1 \mathrm{MO}-1\end{array}$ & $\begin{array}{l}\text { EOT } \sim 50 \% \\
3 / 12 \sim 70 \% \\
\text { Hematuria } 88 \% \\
\text { Dysuria and frequency } 70 \%- \\
80 \% \\
\text { Pain NR }\end{array}$ & SDFS $9 / 12$ & $\begin{array}{l}\sim 30 \% \\
>\mathrm{G} 2<1 \%\end{array}$ \\
\hline $\begin{array}{l}\text { McLaren et al. }{ }^{[20]} \\
\text { (Prospective cohort) }\end{array}$ & $\begin{array}{l}30 \text { Gy } 6 \# \\
36 \text { Gy } 6 \#\end{array}$ & $\begin{array}{l}\text { T2-4NO- } \\
1 \mathrm{MO}-1\end{array}$ & $\begin{array}{l}1 / 12 ~ 73 \% \\
\text { Hematuria } 92 \% \\
\text { Dysuria and frequency 52\% }\end{array}$ & SDFS $7 / 12$ & $\begin{array}{l}43 \% \\
>\mathrm{G} 2 \\
\text { Urinary } 18 \% \\
\text { Bowel } 8 \%\end{array}$ \\
\hline $\begin{array}{l}\text { Kouloulias et al. }{ }^{[21]} \\
\text { (Prospective cohort) }\end{array}$ & 36 Gy 6\# & T1-2NOMO & $\begin{array}{l}\text { Hematuria } 94.8 \% \\
\text { Dysuria } 44 \% \\
\text { Frequency } 57 \%\end{array}$ & PFS $14 / 12$ & $\begin{array}{l}28 \%-49.9 \% \\
>\mathrm{G} 20 \%\end{array}$ \\
\hline $\begin{array}{l}\text { Jose et al }{ }^{[22]} \\
\text { (Phase } 11 \text { clinical trial) }\end{array}$ & $\begin{array}{l}30 \text { Gy 6\# } \\
36 \text { Gy 6\# } \\
24 \text { Gy } 4 \# \\
18 \text { Gy 3\# } \\
12 \text { Gy 2\# }\end{array}$ & $\begin{array}{l}\text { T2-4NO- } \\
3 \mathrm{MO}-1\end{array}$ & $50 \%-63 \%$ & OS $8 / 12$ & $\begin{array}{l}\text { Bowel } 36 \% \\
\text { Bladder 63\% } \\
>\text { G2 } 14 \%\end{array}$ \\
\hline $\begin{array}{l}\text { Dirix et al. }{ }^{[23]} \\
\text { (Prospective cohort) }\end{array}$ & 34.5 Gy 6\# & $\begin{array}{l}\text { T1-4N1- } \\
3 \mathrm{MO}-1\end{array}$ & $\begin{array}{l}\text { Hematuria 90\% } \\
\text { Others-NR }\end{array}$ & $\begin{array}{l}\text { SDFS } 13 / 12 \\
\text { (Hematuria) } \\
\text { OS } 10.5 / 12\end{array}$ & $\begin{array}{l}\text { Bowel 9\% } \\
\text { Bladder 55\% } \\
>\text { G2 } \\
\text { Bowel 0\% } \\
\text { Bladder } 9 \%\end{array}$ \\
\hline
\end{tabular}

EOT: End of treatment; > G2: Grade 3 or higher toxicity; NR: not reported; OS: overall survival; PFS: progression-free survival; SDFS: symptomatic disease-free survival.

\section{Bone metastases}

Bone metastases are seen in up to $50 \%$ of those with metastatic urothelial carcinoma. However, it is limited to the bone in less than $10 \%^{[25-27]}$. Bone metastases have the potential to cause pain, spinal cord compression and fractures, and radiotherapy is commonly used as a palliative and preventive measure.

In metastatic bladder cancer, current accepted palliative radiotherapy practices are applicable. Both single and multiple fractionation schedules are in use. Several large systematic reviews evaluating the evidence for radiotherapy in bone metastases are in existence. Although the latest evidence suggests there is a slightly lower overall response rate [ $72 \%$ vs. $75 \%, \mathrm{OR}=0.96,(95 \% \mathrm{CI}: 0.93-0.99)]$ and an increased need for retreatment $[\mathrm{OR}=2.38,(95 \% \mathrm{CI}: 1.84-3.08)]$ with 8 Gy single fraction compared to multi-fraction treatments, the clinical significance of this is questionable for patients with metastatic urothelial cancers in view of their poor prognosis ${ }^{[28,29]}$.

In a recent review, $10 \mathrm{~Gy}$ single dose treatment had the best pain response and the need for re-treatment, incidence of pathological fractures and spinal cord compression were reduced with the increase in dose per fraction. However, the majority of data is for $8 \mathrm{~Gy}$ single dose treatment and demonstrates high efficacy despite the retreatment rate of $20 \%-30 \%$, with low rates of other complications such as pathological fracture (4\%) and spinal cord compression $(3 \%)^{[30]}$. Amongst the many multiple fraction schedules commonly used, $22.5 \mathrm{~Gy}$ in 5 fractions was seen to have the highest overall response (ORR) rate, 30 Gy in 15 fractions, the best complete response (CRR) rate and $20 \mathrm{~Gy}$ in 2 fractions, the best partial response rate (PRR) in a systematic review. Interestingly, the commonly used palliative schedules, $20 \mathrm{~Gy}$ in 5 fractions and $30 \mathrm{~Gy}$ in 10 fractions were found to be only moderately effective with ORR of $60 \%$ and $51 \%$. Their CRR was $24 \%$ and 
$14 \%$, while retreatment was needed in $16 \%$ and $11 \%$, respectively ${ }^{[31]}$. The number of bladder cancer cases in the published meta-analyses is small with only 4 studies specifying it as a significant contributor as seen in Table 2.

\section{Brain metastases}

Brain metastases are rare in urothelial cancers affecting only about $5 \%$ of patients at presentation. They are commonly found together with thoracic and bone metastases ${ }^{[25]}$. The management remains similar to brain metastases from other common primary carcinomas. Radiotherapy may be used adjuvant to surgical resection or as a primary modality with stereotactic radiosurgery (SRS) for localised metastases and whole brain radiotherapy for multiple metastases.

Most of the data on the effectiveness of these treatments in urothelial cancer patients comes from single institutional reviews. An exploratory patient-point meta-analysis based on a comprehensive literature review including 85 publications found the median residual survival from time of diagnosis of brain metastases to be around 3 months (95\%CI: 2.9-3.7). Longer survival was only significantly associated with metastasectomy in those with single brain metastasis (9 months, 95\%CI: 6.1-11.9 vs. 2 months without resection, 95\%CI: 1.1-2.9, $P<0.001$ ). This benefit with surgery was not seen in those with multiple deposits. No survival benefit was seen with radiotherapy. There was no analysis of symptom relief or quality of life $(\mathrm{QoL})^{[58]}$.

Adjuvant whole brain or stereotactic radiotherapy is known to reduce local recurrence and death from neurological causes ${ }^{[59-65]}$. However, there was minimal contribution from urothelial carcinoma patients in the published studies due to its rarity. In one of the larger series of 62 bladder cancer patients with brain metastases, there was no survival benefit with surgery plus radiotherapy over radiotherapy alone ${ }^{[6]]}$.

Whole brain radiotherapy (WBRT) is conventionally used for palliation in those ineligible for surgery or SRS. Most bladder cancer patients will fall into this category due to age, comorbidities, and the presence of extracranial metastases. No fractionation schedule has been shown to be superior to others ${ }^{[67]}$ and in the Radiation Therapy Oncology Group studies from the 1970s, over 60\% symptom improvement was reported. A large randomised trial in non-small cell lung cancer, the Quality of Life after Treatment for Brain Metastases, failed to find a benefit for WBRT over best supportive care, with regards to OS and QoL ${ }^{[6,69]}$. Any benefit from radiotherapy for multiple brain metastases may be limited to young patients with very good performance status.

\section{Consolidation radiotherapy}

Primary tumour

The potential survival benefit in patients with metastatic disease of controlling the initial disease burden by localized therapies alongside systemic therapy has been explored in a few studies with interesting results.

One retrospective analysis amongst patients receiving systemic therapy for metastatic disease found a significantly longer median overall survival (14.9 months $v s$. 9.9 months) when radical cystectomy or radical radiotherapy (> $50 \mathrm{~Gy}$ ) to the bladder was also used compared to those who received conservative palliative local treatment only. In addition, those who received radiotherapy to consolidate a response to chemotherapy did better than those selected for a cytoreductive approach with local treatment before chemotherapy (median OS 17.7 months vs. 12.4 months) ${ }^{[70]}$. This is supported by a population-based study from the United States, which showed improved OS and cause-specific survival with radical cystectomy in patients with solitary metastases ${ }^{[71]}$. 
Table 2. Studies with bladder cancer patients included in the 2 meta-analyses ${ }^{[30,31]}$

\begin{tabular}{|c|c|c|c|}
\hline Study & Fraction of bladder cancer patients & Non specified primary site & Dose fractionation \\
\hline Niewald et al. ${ }^{[32]}$ & $4 / 100$ & 0 & 30 Gy 15\# vs. 20 Gy 5\# \\
\hline Madsen $^{[33]}$ & $2 / 57$ & 0 & 24 Gy $6 \#$ vs. 20 Gy 2\# \\
\hline Anter ${ }^{[34]}$ & $7 / 100$ & 2 & 8 Gy 1\# vs. 20 Gy 5\# \\
\hline Hoskin et al. ${ }^{[35]}$ & $13 / 655$ & 13 & 8 Gy 1\# vs. 4 Gy 1\# \\
\hline Roos et al..$^{[36]}$ & $0 / 272$ & 86 & 8 Gy $1 \#$ vs. 20 Gy 5\# \\
\hline Foro Arnalot et al. ${ }^{[37]}$ & $0 / 160$ & 8 & 8 Gy $1 \#$ vs. 30 Gy $10 \#$ \\
\hline Okawa et al. ${ }^{[38]}$ & $0 / 80$ & 2 & 30 Gy $15 \#$ vs. 22.5 Gy 5\# vs. 20 Gy 10\# \\
\hline Neilson et al. ${ }^{[39]}$ & $0 / 241$ & 34 & 8 Gy 1\# vs. 20 Gy 5\# \\
\hline Steenland et al. ${ }^{[40]}$ & $0 / 1171$ & 150 & 24 Gy $6 \#$ vs. 8 Gy $1 \#$ \\
\hline Price et al. ${ }^{[41]}$ & $0 / 288$ & 68 & 8 Gy $1 \#$ vs. 30 Gy $10 \#$ \\
\hline Cole $^{[42]}$ & $0 / 29$ & 4 & 24 Gy 6\# vs. 8 Gy 1\# \\
\hline Gaze et al. ${ }^{[43]}$ & $0 / 265$ & 38 & 22.5 Gy 5\# vs. 10 Gy 1\# \\
\hline Majumder et al. ${ }^{[44]}$ & $0 / 64$ & 0 & 8 Gy 1\# vs. 30 Gy 10\# \\
\hline Hartsell et al. ${ }^{[45]}$ & $0 / 498$ & NS & 8 Gy $1 \#$ vs. 30 Gy $10 \#$ \\
\hline Gutiérrez Bayard et al. ${ }^{[46]}$ & $0 / 98$ & 18 & 8 Gy $1 \#$ vs. 30 Gy $10 \#$ \\
\hline Badzio et al. ${ }^{[47]}$ & $0 / 115$ & 28 & 8 Gy $1 \#$ vs. 20 Gy $5 \#$ \\
\hline Amouzegar-Hashemi et al. ${ }^{[48]}$ & NS & 70 & 8 Gy $1 \#$ vs. 30 Gy $10 \#$ \\
\hline Berwouts et al. ${ }^{[49]}$ & $0 / 45$ & 7 & 8 Gy 1\# vs. 16 Gy 1\# \\
\hline Bone pain trial $^{[50]}$ & NS & 65 & 8 Gy $1 \#$ vs. 20 Gy $5 \#$ vs. 30 Gy $10 \#$ \\
\hline Guden et al. $^{[51]}$ & $0 / 62$ & 19 & 6 Gy $1 \#$ \\
\hline Hayashi et al. ${ }^{[52]}$ & $0 / 28$ & 0 & Multiple \\
\hline Hoskin et al. $^{[53]}$ & $0 / 270$ & 41 & 8 Gy $1 \#$ vs. 4 Gy $1 \#$ \\
\hline Jeremic et al. ${ }^{[54]}$ & $0 / 327$ & 17 & 8 Gy 1\# vs. 6 Gy $1 \#$ vs. 4 Gy 1\# \\
\hline Nuzzo et al. ${ }^{[55]}$ & $0 / 248$ & 248 & 8 Gy $1 \#$ \\
\hline Price et al. ${ }^{[56]}$ & $0 / 26$ & 0 & 4 Gy $1 \#$ \\
\hline Uppelschoten $^{[57]}$ & $0 / 170$ & NS & 6 Gy $1 \#$ \\
\hline
\end{tabular}

NS: Not specified; \#: fraction.

Lymph nodes

Lymph node only metastasis carries a better prognosis than other metastatic sites ${ }^{[71,72]}$. Treatments strategies include chemotherapy and chemo-radiotherapy. The Intensity-Modulated Pelvic Node and Bladder Radiotherapy trial in bladder cancer has shown the safety and long-term disease control benefits of simultaneously boosting involved pelvic lymph nodes to $60 \mathrm{~Gy}$ in 32 fractions with low late toxicity rates of only $5 \%{ }^{[73]}$. The safety of radical pelvic lymph node treatments is also demonstrated in other studies ${ }^{[74,75]}$.

\section{Distant metastasis-directed therapy}

Cancer-specific and overall survival in patients with metastatic urothelial carcinoma depends on the sites of visceral involvement and the number of deposits. Those with a single metastatic deposit in the lung or bone have better survival than those with liver involvement. Distal lymph node only metastasis have significantly better survival than involvement of other sites as shown in Figure $1^{[71]}$. This has been reported in other series also and has led to defining the M1a sub staging of distal lymph node only metastasis in the AJCC 8th edition $^{[7,76,77]}$.

Several surgical series have looked at the potential benefits of metastasectomy in this setting. A multiinstitutional retrospective review from Japan showed a significantly longer median survival for solitary lymph node or lung metastasis than for other sites (81 months vs. 19 months) ${ }^{[11]}$. Metastasectomy, especially 


\section{Overall survival}

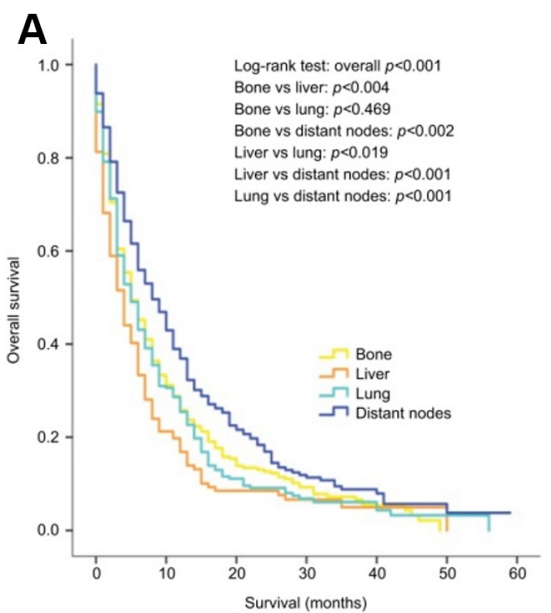

\section{Cause specific survival}

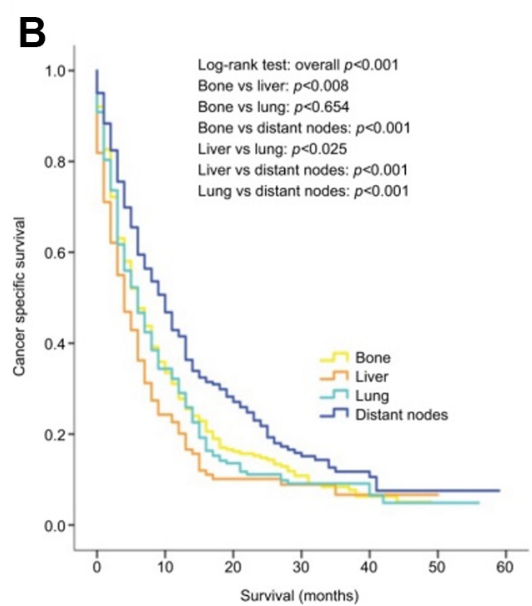

Figure 1. Kaplan-Meier curves of overall survival (A) and cancer-specific survival (B) according to the sites of metastases in patients with single metastatic site (Reproduced from Ref. ${ }^{[71]}$ ).

when the disease is limited to the lung, is supported by several studies with some showing median overall survival in excess of 2 years following complete resection ${ }^{[12-16]}$. Based on findings such as these the latest European Association of Urology, European Association of Medical Oncology guideline on advanced urothelial carcinoma recommends consideration of radical treatment in the presence of a single metastatic site as it is potentially curable ${ }^{[6]}$.

Although there is a growing evidence base for ablation of metastatic deposits using radiotherapy, data specific for urothelial cancers are scarce. Recently presented long-term results of the SABR-COMET study comparing stereotactic radiotherapy (SBRT) with palliative treatment in those with a controlled primary and 1-5 metastatic deposits shows improved median OS of 50 months vs. 28 months $(P=0.006)$ along with improved PFS and local site control. However, the proportion of bladder cancer patients included in this study is not stated ${ }^{[78,79]}$. Others also have seen similar survival benefit with SBRT in those with oligometastatic disease, but again the number of patients included with urothelial cancer is either small or not stated ${ }^{[80-83]}$. There are few published SBRT studies that are specific to bladder cancer. An Italian single institution retrospective review of stereotactic irradiation of synchronous lymph node only metastases from urothelial carcinoma reported a local control rate of $100 \%$ at 2 months with 6 out of 14 target lesions showing partial response and 8 remaining stable. The median treated lymph node PFS was 11.4 months (95\%CI: 3.4-19.4), but overall PFS was 2.9 months (95\%CI: 2.6-3.1) and OS was 14.9 months (95\%CI: $12.3-$ $17.5)^{[84]}$. SBRT using Cyberknife stereotactic radiotherapy to bone, lung and lymph node metastases in urothelial cancer has been reported with one-third remaining disease-free at 30 months with no major toxicity $^{[85]}$.

In another study, following partial response to cisplatin-based chemotherapy for nodal or distal metastases consolidation radiotherapy to residual sites of disease resulted in a median RFS of 19 months and OS of 49 months for the whole cohort of 22 patients with 2 patients having single lung and mediastinal deposits surviving over 6 years $^{[86]}$. A similar OS benefit of $43 \%$ at 3 years with consolidation radiotherapy to metastasis following cisplatin-based chemotherapy has been reported; however, when controlled for sex, performance status, haemoglobin level and number of organs with metastasis, this was not associated with longer survival $(\mathrm{HR}=0.666, P=0.0966)$. Metastasectomy however, remained significantly associated with 
improved OS $(\mathrm{HR}=0.358, P=0.0006)^{[87]}$. In another larger Italian retrospective series in patient with controlled primary disease, the 2-year local control was $88.9 \%$ (95\%CI: 76.1\%-95.1\%) for those with 1 to 5 metastases. The 2-year distant and overall PFS for the entire cohort was around $40 \%$ with a median 12 month freedom from start or change of systemic therapy. Inferior local control was associated with the number of prior lines of systemic therapies, and PFS was associated with the number of metastases. The reported median OS was 25.6 months which correlated with total dose and biologically equivalent dose $\left(\mathrm{BED}_{10}\right)$ in univariate analysis ${ }^{[88]}$.

Clearly, further studies are needed to identify metastatic bladder cancer patients who may benefit from these radical ablative treatments alongside systemic therapy.

\section{Radiotherapy and immunotherapy combination}

There is a growing pool of preclinical and early phase clinical trial data that suggests radiotherapy and immunotherapy act synergistically in cancer treatments. The effect is thought to be mediated by radiotherapy reducing tumour growth allowing time for immunotherapy to act, altering the tumour immune microenvironment to increase susceptibility to immunotherapy and through the abscopal effect ${ }^{[89]}$. A phase $1 \mathrm{~b}$ study has shown the combination of durvalumab with radiotherapy for locally advanced unresectable non-metastatic bladder cancers to be safe with a $70 \%$ complete clinical response rate ${ }^{[00,91]}$. A further phase II clinical trial, NCT03115801 is investigating the place of immunomodulation using nivolumab, atezolizumab or pembrolizumab alone $v s$. in combination with radiotherapy 30 Gy in 10 fractions for metastatic urothelial and renal cancers ${ }^{\left[{ }^{[2]}\right]}$. This is likely to be an area of considerable interest and trial activity in the forthcoming years.

\section{CONCLUSION}

The conventional and historical place of radiotherapy in metastatic bladder cancer is in palliation, where it offers effective symptom control in haematuria and symptomatic bone and brain metastases. However, in those with limited metastatic disease, fit for systemic therapy, consolidation for those responding to systemic agents with surgery or radiotherapy may be beneficial. Given the poor overall survival in these patients, selection of patients for either treatment needs to be streamlined to ensure they are offered only to those who will live long enough to benefit. Further bladder cancer-specific data is needed to help guide clinicians in individualizing these treatments.

\section{DECLARATIONS}

\section{Acknowledgments}

Peter Hoskin is supported by the NIHR Manchester Biomedical Research Centre.

\section{Author's contributions}

Design, review of evidence and interpretation of the data presented: Perera J, Hoskin P

\section{Availability of data and materials}

All data referred to in this paper is available in the referenced publications.

\section{Financial support and sponsorship}

None.

\section{Conflicts of interests}

Both authors declared that there are no conflicts of interest. 


\section{Ethical approval and consent to participate}

Not applicable.

\section{Consent for publication}

Not applicable.

\section{Copyright}

(c) The Author(s) 2022.

\section{REFERENCES}

1. Antoni S, Ferlay J, Soerjomataram I, Znaor A, Jemal A, Bray F. Bladder cancer incidence and mortality: a global overview and recent trends. Eur Urol 2017;71:96-108. DOI PubMed

2. Bray F, Ferlay J, Soerjomataram I, Siegel RL, Torre LA, Jemal A. Global cancer statistics 2018: GLOBOCAN estimates of incidence and mortality worldwide for 36 cancers in 185 countries. CA Cancer J Clin 2018;68:394-424. DOI PubMed

3. Cancer Research UK. Bladder cancer. Available from: https://www.cancerresearchuk.org/health-professional/cancerstatistics/statistics-by-cancer-type/bladder-cancer [Last accessed on 14 Jan 2021].

4. Ghoneim MA, Abdel-Latif M, el-Mekresh M, et al. Radical cystectomy for carcinoma of the bladder: 2,720 consecutive cases 5 years later. J Urol 2008;180:121-7. DOI PubMed

5. Mari A, Campi R, Tellini R, et al. Patterns and predictors of recurrence after open radical cystectomy for bladder cancer: a comprehensive review of the literature. World J Urol 2018;36:157-70. DOI PubMed PMC

6. Witjes JA, Bruins HM, Cathomas R, et al; Members of the European Association of Urology (EAU) Guidelines Panel. EAU Guidelines on muscle invasive and metastatic bladder cancer. Available from: https://uroweb.org/guideline/bladder-cancer-muscleinvasive-and-metastatic/ [Last accessed on 14 Jan 2021].

7. von der Maase H, Sengelov L, Roberts JT, et al. Long-Term survival results of a randomized trial comparing gemcitabine plus cisplatin, with methotrexate, vinblastine, doxorubicin, plus cisplatin in patients with bladder cancer. J Clin Oncol 2005;23:4602-8. DOI PubMed

8. Balar AV, Galsky MD, Rosenberg JE, et al. Atezolizumab as first-line treatment in cisplatin-ineligible patients with locally advanced and metastatic urothelial carcinoma: a single-arm, multicentre, phase 2 trial. Lancet 2017;389:67-76. DOI PubMed PMC

9. Powles T, Park SH, Voog E, et al. Avelumab maintenance therapy for advanced or metastatic urothelial carcinoma. $N$ Engl $J$ Med 2020;383:1218-30. DOI PubMed

10. Sternberg CN, de Mulder P, Schornagel JH, et al; EORTC Genito-Urinary Cancer Group. Seven year update of an EORTC phase III trial of high-dose intensity M-VAC chemotherapy and G-CSF versus classic M-VAC in advanced urothelial tract tumours. Eur $J$ Cancer 2006;42:50-4. DOI PubMed

11. Abe T, Kitamura H, Obara W, et al. Outcome of metastasectomy for urothelial carcinoma: a multi-institutional retrospective study in Japan. J Urol 2014;191:932-6. DOI PubMed

12. Kim T, Ahn JH, You D, et al. Pulmonary metastasectomy could prolong overall survival in select cases of metastatic urinary tract cancer. Clin Genitourin Cancer 2015;13:e297-304. DOI PubMed

13. Patel V, Collazo Lorduy A, Stern A, et al. Survival after metastasectomy for metastatic urothelial carcinoma: a systematic review and meta-analysis. Bladder Cancer 2017;3:121-32. DOI PubMed PMC

14. Abufaraj M, Dalbagni G, Daneshmand S, et al. The role of surgery in metastatic bladder cancer: a systematic review. Eur Urol 2018;73:543-57. DOI PubMed PMC

15. Siefker-Radtke AO, Walsh GL, Pisters LL, et al. Is there a role for surgery in the management of metastatic urothelial cancer? $J$ Urol 2004;171:145-8. DOI PubMed

16. Iwamoto H, Izumi K, Shimura Y, et al. Metastasectomy improves survival in patients with metastatic urothelial carcinoma. Anticancer Res 2016;36:5557-61. DOI PubMed

17. Lydon A, Duchesne GM. How should we palliate bladder cancer? Clin Oncol (R Coll Radiol) 1992;4:273-4. DOI PubMed

18. Ali A, Song YP, Mehta S, et al. Palliative radiation therapy in bladder cancer-importance of patient selection: a retrospective multicenter study. Int J Radiat Oncol Biol Phys 2019;105:389-93. DOI PubMed

19. Duchesne GM, Bolger JJ, Griffiths GO, et al. A randomized trial of hypofractionated schedules of palliative radiotherapy in the management of bladder carcinoma: results of medical research council trial BA09. Int J Radiat Oncol Biol Phys 2000;47:379-88. DOI PubMed

20. McLaren DB, Morrey D, Mason MD. Hypofractionated radiotherapy for muscle invasive bladder cancer in the elderly. Radiother Oncol 1997;43:171-4. DOI PubMed

21. Kouloulias V, Tolia M, Kolliarakis N, Siatelis A, Kelekis N. Evaluation of acute toxicity and symptoms palliation in a hypofractionated weekly schedule of external radiotherapy for elderly patients with muscular invasive bladder cancer. Int Braz $J$ Urol 2013;39:77-82. DOI PubMed

22. Jose CC, Price A, Norman A, et al. Hypofractionated radiotherapy for patients with carcinoma of the bladder. Clin Oncol (R Coll Radiol) 1999;11:330-3. DOI PubMed

23. Dirix P, Vingerhoedt S, Joniau S, Van Cleynenbreugel B, Haustermans K. Hypofractionated palliative radiotherapy for bladder cancer. 
Support Care Cancer 2016;24:181-6. DOI PubMed

24. Fosså SD, Hosbach G. Short-term moderate-dose pelvic radiotherapy of advanced bladder carcinoma. A questionnaire-based evaluation of its symptomatic effect. Acta Oncol 1991;30:735-8. DOI PubMed

25. Bianchi M, Roghmann F, Becker A, et al. Age-stratified distribution of metastatic sites in bladder cancer: a population-based analysis. Can Urol Assoc J 2014;8:E148-58. DOI PubMed PMC

26. Necchi A, Pond GR, Pal SK, et al; Retrospective International Study of Invasive/Advanced Cancer of the Urothelium Group. Bone metastases as the only metastatic site in patients with urothelial carcinoma: focus on a special patient population. Clin Genitourin Cancer 2018;16:e483-90. DOI PubMed PMC

27. Shinagare AB, Ramaiya NH, Jagannathan JP, Fennessy FM, Taplin ME, Van den Abbeele AD. Metastatic pattern of bladder cancer: correlation with the characteristics of the primary tumor. AJR Am J Roentgenol 2011;196:117-22. DOI PubMed

28. Rich SE, Chow R, Raman S, et al. Update of the systematic review of palliative radiation therapy fractionation for bone metastases. Radiother Oncol 2018;126:547-57. DOI PubMed

29. Chow R, Hoskin P, Schild SE, et al. Single vs multiple fraction palliative radiation therapy for bone metastases: cumulative metaanalysis. Radiother Oncol 2019;141:56-61. DOI PubMed

30. Chow R, Hoskin P, Hollenberg D, et al. Efficacy of single fraction conventional radiation therapy for painful uncomplicated bone metastases: a systematic review and meta-analysis. Ann Palliat Med 2017;6:125-42. DOI PubMed

31. Chow R, Hoskin P, Chan S, et al. Efficacy of multiple fraction conventional radiation therapy for painful uncomplicated bone metastases: a systematic review. Radiother Oncol 2017;122:323-31. DOI PubMed

32. Niewald M, Tkocz HJ, Abel U, et al. Rapid course radiation therapy vs. more standard treatment: a randomized trial for bone metastases. Int J Radiat Oncol Biol Phys ;36:1085-9. DOI PubMed

33. Madsen EL. Painful bone metastasis: efficacy of radiotherapy assessed by the patients: a randomized trial comparing 4 Gy X 6 versus 10 Gy X 2. Int J Radiat Oncol Biol Phys 1983;9:1775-9. DOI PubMed

34. Anter A. Single fraction versus multiple fraction radiotherapy for treatment of painful bone metastases: a prospective study; Mansoura experience. Forum Clin Oncol 2015;6:8-13. DOI

35. Hoskin P, Rojas A, Fidarova E, et al. IAEA randomised trial of optimal single dose radiotherapy in the treatment of painful bone metastases. Radiother Oncol 2015;116:10-4. DOI PubMed

36. Roos DE, Turner SL, O'Brien PC, et al; Trans-Tasman Radiation Oncology Group; TROG 96. 05. Randomized trial of 8 Gy in 1 versus 20 Gy in 5 fractions of radiotherapy for neuropathic pain due to bone metastases (Trans-Tasman Radiation Oncology Group, TROG 96.05). Radiother Oncol 2005;75:54-63. DOI PubMed

37. Foro Arnalot P, Fontanals AV, Galcerán JC, et al. Randomized clinical trial with two palliative radiotherapy regimens in painful bone metastases: 30 Gy in 10 fractions compared with 8 Gy in single fraction. Radiother Oncol 2008;89:150-5. DOI PubMed

38. Okawa T, Kita M, Goto M, Nishijima H, Miyaji N. Randomized prospective clinical study of small, large and twice-a-day fraction radiotherapy for painful bone metastases. Radiother Oncol 1988;13:99-104. DOI PubMed

39. Nielsen OS, Bentzen SM, Sandberg E, Gadeberg CC, Timothy AR. Randomized trial of single dose versus fractionated palliative radiotherapy of bone metastases. Radiother Oncol 1998;47:233-40. DOI PubMed

40. Steenland E, Leer J, van Houwelingen H, et al. The effect of a single fraction compared to multiple fractions on painful bone metastases: a global analysis of the Dutch Bone Metastasis Study. Radiother Oncol 1999;52:101-9. DOI PubMed

41. Price P, Hoskin P, Easton D, Austin D, Palmer S, Yarnold J. Prospective randomised trial of single and multifraction radiotherapy schedules in the treatment of painful bony metastases. Radiother Oncol 1986;6:247-55. DOI PubMed

42. Cole DJ. A randomized trial of a single treatment versus conventional fractionation in the palliative radiotherapy of painful bone metastases. Clin Oncol (R Coll Radiol) 1989;1:59-62. DOI PubMed

43. Gaze MN, Kelly CG, Kerr GR, et al. Pain relief and quality of life following radiotherapy for bone metastases: a randomised trial of two fractionation schedules. Radiother Oncol 1997;45:109-16. DOI PubMed

44. Majumder D, Chatterjee D, Bandyopadhyay A, Mallick SK, Sarkar SK, Majumdar A. Single fraction versus multiple fraction radiotherapy for palliation of painful vertebral bone metastases: a prospective study. Indian J Palliat Care 2012;18:202-6. DOI PubMed PMC

45. Hartsell WF, Scott CB, Bruner DW, et al. Randomized trial of short- versus long-course radiotherapy for palliation of painful bone metastases. J Natl Cancer Inst 2005;97:798-804. DOI PubMed

46. Gutiérrez Bayard L, Salas Buzón Mdel C, Angulo Paín E, de Ingunza Barón L. Radiation therapy for the management of painful bone metastases: results from a randomized trial. Rep Pract Oncol Radiother 2014;19:405-11. DOI PubMed PMC

47. Badzio A, Senkus-Konefka E, Jereczek-Fossa BA, et al. 20 Gy in five fractions versus 8 Gy in one fraction in palliative radiotherapy of bone metastases. A multicentre randomized study. Nowotwory 2003;53:261-4. DOI

48. Amouzegar-Hashemi F, Behrouzi H, Kazemian A, Zarpak B, Haddad P. Single versus multiple fractions of palliative radiotherapy for bone metastases: a randomized clinical trial in Iranian patients. Curr Oncol 2008;15:151. DOI PubMed PMC

49. Berwouts D, De Wolf K, Lambert B, et al. Biological 18[F]-FDG-PET image-guided dose painting by numbers for painful uncomplicated bone metastases: a 3-arm randomized phase II trial. Radiother Oncol 2015;115:272-8. DOI PubMed

50. 8 Gy single fraction radiotherapy for the treatment of metastatic skeletal pain: randomised comparison with a multifraction schedule over 12 months of patient follow-up. Bone Pain Trial Working Party. Radiother Oncol 1999;52:111-21. PubMed

51. Güden M, Kurt E, Ulutin C. Six gray single dose radiotherapy in the treatment of metastatic bone pain. Tohoku J Exp Med 2002;197:111-4. DOI PubMed

52. Hayashi S, Tanaka H, Hoshi H. External beam radiotherapy for painful bone metastases from hepatocellular carcinoma: multiple 
fractions compared with an 8-Gy single fraction. Nagoya J Med Sci 2014;76:91-9. PubMed PMC

53. Hoskin PJ, Price P, Easton D, Regan J, Austin D, Palmer S, Yarnold JR. A prospective randomised trial of 4 Gy or 8 Gy single doses in the treatment of metastatic bone pain. Radiother Oncol 1992;23:74-8. DOI PubMed

54. Jeremic B, Shibamoto Y, Acimovic L, et al. A randomized trial of three single-dose radiation therapy regimens in the treatment of metastatic bone pain. Int J Radiat Oncol Biol Phys 1998;42:161-7. DOI PubMed

55. Nuzzo M, Macchia G, Torre G, et al. Single fraction radiotherapy ( $8 \mathrm{~Gy}$ ) on painful bone metastases with involvement of the adjacent soft tissues. Radiother Oncol 2015;115:S697-8. DOI

56. Price P, Hoskin PJ, Easton D, Austin D, Palmer S, Yarnold JR. Low dose single fraction radiotherapy in the treatment of metastatic bone pain: a pilot study. Radiother Oncol 1988;12:297-300. DOI PubMed

57. Uppelschoten JM, Wanders SL, de Jong JM. Single-dose radiotherapy (6 Gy): palliation in painful bone metastases. Radiother Oncol 1995;36:198-202. DOI PubMed

58. Diamantopoulos LN, Khaki AR, Sonpavde GP, et al. Central nervous system metastasis in patients with urothelial carcinoma: institutional experience and a comprehensive review of the literature. Clin Genitourin Cancer 2020;18:e266-76. DOI PubMed PMC

59. Patchell RA, Tibbs PA, Regine WF, et al. Postoperative radiotherapy in the treatment of single metastases to the brain: a randomized trial. JAMA 1998;280:1485-9. DOI PubMed

60. Rosenstein M, Wallner K, Scher H, Sternberg CN. Treatment of brain metastases from bladder cancer. J Urol 1993;149:480-3. DOI PubMed

61. Mahmoud-Ahmed AS, Suh JH, Kupelian PA, Klein EA, Peereboom DM, Dreicer R, Barnett GH. Brain metastases from bladder carcinoma: presentation, treatment and survival. J Urol 2002;167:2419-22. PubMed

62. Roos DE, Wirth A, Burmeister BH, et al. Whole brain irradiation following surgery or radiosurgery for solitary brain metastases: mature results of a prematurely closed randomized Trans-Tasman Radiation Oncology Group trial (TROG 98.05). Radiother Oncol 2006;80:318-22. DOI PubMed

63. Kocher M, Soffietti R, Abacioglu U, et al. Adjuvant whole-brain radiotherapy versus observation after radiosurgery or surgical resection of one to three cerebral metastases: results of the EORTC 22952-26001 study. J Clin Oncol 2011;29:134-41. DOI PubMed PMC

64. Tsao M, Xu W, Sahgal A. A meta-analysis evaluating stereotactic radiosurgery, whole-brain radiotherapy, or both for patients presenting with a limited number of brain metastases. Cancer 2012;118:2486-93. DOI PubMed

65. Brown PD, Ballman KV, Cerhan JH, et al. Postoperative stereotactic radiosurgery compared with whole brain radiotherapy for resected metastatic brain disease (NCCTG N107C/CEC.3): a multicentre, randomised, controlled, phase 3 trial. Lancet Oncol 2017;18:1049-60. DOI PubMed PMC

66. Fokas E, Henzel M, Engenhart-Cabillic R. A comparison of radiotherapy with radiotherapy plus surgery for brain metastases from urinary bladder cancer: analysis of 62 patients. Strahlenther Onkol 2010;186:565-71. DOI PubMed

67. Khuntia D, Brown P, Li J, Mehta MP. Whole-brain radiotherapy in the management of brain metastasis. J Clin Oncol 2006;24:1295304. DOI PubMed

68. Borgelt B, Gelber R, Larson M, Hendrickson F, Griffin T, Roth R. Ultra-rapid high dose irradiation schedules for the palliation of brain metastases: Final results of the first two studies by the radiation therapy oncology group. Int $J$ Radiat Oncol Biol Phys 1981;7:1633-8. DOI PubMed

69. Mulvenna P, Nankivell M, Barton R, et al. Dexamethasone and supportive care with or without whole brain radiotherapy in treating patients with non-small cell lung cancer with brain metastases unsuitable for resection or stereotactic radiotherapy (QUARTZ): results from a phase 3, non-inferiority, randomised trial. Lancet 2016;388:2004-14. DOI PubMed PMC

70. Seisen T, Sun M, Leow JJ, et al. Efficacy of high-intensity local treatment for metastatic urothelial carcinoma of the bladder: a propensity score-weighted analysis from the national cancer data base. J Clin Oncol 2016;34:3529-36. DOI PubMed

71. Dong F, Shen Y, Gao F, et al. Prognostic value of site-specific metastases and therapeutic roles of surgery for patients with metastatic bladder cancer: a population-based study. Cancer Manag Res 2017;9:611-26. DOI PubMed PMC

72. Bajorin DF, Dodd PM, Mazumdar M, et al. Long-term survival in metastatic transitional-cell carcinoma and prognostic factors predicting outcome of therapy. J Clin Oncol 1999;17:3173-81. DOI PubMed

73. Tan MP, Harris V, Warren-Oseni K, et al. The intensity-modulated pelvic node and bladder radiotherapy (IMPART) trial: a phase II single-centre prospective study. Clin Oncol (R Coll Radiol) 2020;32:93-100. DOI PubMed PMC

74. Fackrell DG, Ford D, Chetiyawardana S, Austin S, James N. The delivery of radical radiotherapy to the bladder and pelvis in nodepositive (N1) bladder cancer: a five patient case series. BJR Case Rep 2017;3:20160102. DOI PubMed PMC

75. Søndergaard J, Høyer M, Petersen JB, Wright P, Grau C, Muren LP. The normal tissue sparing obtained with simultaneous treatment of pelvic lymph nodes and bladder using intensity-modulated radiotherapy. Acta Oncol 2009;48:238-44. DOI PubMed

76. Amin MB, Edge S, Greene F, et al. (Eds.). AJCC cancer staging manual (8th edition). Springer International Publishing: American Joint Commission on Cancer; 2017.

77. Galsky MD, Moshier E, Krege S, et al. Nomogram for predicting survival in patients with unresectable and/or metastatic urothelial cancer who are treated with cisplatin-based chemotherapy. Cancer 2013;119:3012-9. DOI PubMed

78. Palma DA, Olson R, Harrow S, et al. Stereotactic ablative radiotherapy versus standard of care palliative treatment in patients with oligometastatic cancers (SABR-COMET): a randomised, phase 2, open-label trial. Lancet 2019;393:2051-8. DOI PubMed

79. Palma D, Olson R, Harrow S, et al. Stereotactic ablative radiotherapy for the comprehensive treatment of oligometastatic cancers: long-term results of the SABR-COMET randomized trial. Int J Radiat Oncol Biol Phys 2020;108:S88-9. DOI PubMed PMC

80. Chalkidou A, Macmillan T, Grzeda MT, et al. Stereotactic ablative body radiotherapy in patients with oligometastatic cancers: a 
prospective, registry-based, single-arm, observational, evaluation study. Lancet Oncol 2021;22:98-106. DOI PubMed

81. Sutera P, Clump DA, Kalash R, et al. Initial results of a multicenter phase 2 trial of stereotactic ablative radiation therapy for oligometastatic cancer. Int J Radiat Oncol Biol Phys 2019;103:116-22. DOI PubMed

82. Lee YH, Kang KM, Choi HS, et al. Comparison of stereotactic body radiotherapy versus metastasectomy outcomes in patients with pulmonary metastases. Thorac Cancer 2018;9:1671-9. DOI PubMed PMC

83. Ost P, Reynders D, Decaestecker K, et al. Surveillance or metastasis-directed therapy for oligometastatic prostate cancer recurrence: a prospective, randomized, multicenter phase II trial. J Clin Oncol 2018;36:446-53. DOI PubMed

84. Leonetti A, D'Abbiero N, Baldari G, et al. Radiotherapy for the treatment of distant nodes metastases from oligometastatic urothelial cancer: a retrospective case series. Int J Urol 2018;25:879-86. DOI PubMed

85. Augugliaro M, Marvaso G, Ciardo D, et al. Recurrent oligometastatic transitional cell bladder carcinoma: is there room for radiotherapy? Neoplasma 2019;66:160-5. DOI PubMed

86. Shah S, Zhang CA, Hancock S, Fan A, Skinner E, Srinivas S. Consolidative radiotherapy in metastatic urothelial cancer. Clin Genitourin Cancer 2017;15:685-8. DOI PubMed

87. Abe T, Minami K, Harabayashi T, et al. Prognostic impact of local radiotherapy on metastatic urothelial carcinoma patients receiving systemic chemotherapy. Jpn J Clin Oncol 2020;50:206-13. DOI PubMed

88. Franzese C, Francolini G, Nicosia L, Alongi F, Livi L, Scorsetti M. Stereotactic body radiation therapy in the management of oligometastatic and oligoprogressive bladder cancer and other urothelial malignancies. Clin Oncol (R Coll Radiol) 2021;33:50-6. DOI PubMed

89. Ukleja J, Kusaka E, Miyamoto DT. Immunotherapy combined with radiation therapy for genitourinary malignancies. Front Oncol 2021;11:663852. DOI PubMed PMC

90. Joshi M, Tuanquin L, Kaag M, et al. Phase Ib study of concurrent durvalumab and radiation therapy (DUART) followed by adjuvant durvalumab in patients with urothelial cancer of the bladder: BTCRC-GU15-023 study. J Clin Oncol 2018;36:455. DOI

91. Joshi M, Tuanquin L, Kaag M, et al. Concurrent durvalumab and radiation therapy followed by adjuvant durvalumab in patients with locally advanced urothelial cancer of bladder (DUART): Btcrc-GU15-023. J Clin Oncol 2020;38:513. DOI

92. Bethesda (MD): national library of medicine (US). Identifier NCT03115801, a phase II randomized trial of immunotherapy plus radiotherapy in metastatic genitourinary cancers. Available from: http://clinicaltrials.gov/ct/show/NCT0311580 order=1 [Last accessed on 14 Jan 2021]. 